\title{
9. CALIBRATION OF LATE NEOGENE CALCAREOUS PLANKTON DATUM PLANES WITH THE PALEOMAGNETIC RECORD OF SITE 397 AND CORRELATION WITH MOROCCAN AND MEDITERRANEAN SECTIONS
}

\author{
Roberto Mazzei, Institute of Geology, University of Pisa, Pisa, Italy \\ Isabella Raffi and Domenico Rio, Institute of Geology, University of Parma, Parma, Italy \\ Norman Hamilton, Department of Geology, University of Southampton, United Kingdom \\ and \\ Maria Bianca Cita, Department of Geology and Paleontology, University of Milano, Italy
}

\begin{abstract}
The late Neogene succession continuously cored at Hole 397 has been investigated in detail from Cores 69 to 19 to calibrate datum planes based on calcareous nannofossils and planktonic foraminifers with the sequence of magnetic reversals detected in the cores. Nine datum planes based on calcareous nannofossils, 7 based on planktonic foraminifers, and 15 magnetic reversals were detected from Section 57-3 to Core 19. The interval spans 5 m.y., and encompasses paleomagnetic Epoch 7 (partim) to the Matuyama Epoch (partim).

Correlations are presented for the Bou Regreg section of northwestern Morocco; the Melilla section of northern Morocco; Rio Mazzapiedi section of northern Italy (Tortonian stratotype); Cape Rossello, Sicily (Zanclean stratotype); and DSDP Site 132 (Tyrrhenian Basin).

The Tortonian/Messinian, Messinian/Zanclean, and Zanclean/ Piacenzian boundaries are biostratigraphically recognized and located with accuracy.
\end{abstract}

\section{INTRODUCTION}

\section{Purpose}

This report has multiple purposes. First multidisciplinary research on the geodynamic significance of the late Miocene salinity crisis in the Mediterranean has provided an immense body of information and experience, which we wished to utilize to better interpret the sediments cored off Cape Bojador. In particular, the foraminiferal and nannofossil contents of a number of carefully measured stratigraphic successions have been investigated from Italy (d'Onofrio et al., 1975, Rio et al., 1976) and from northern Africa (Bossio et al., 1976; Barbieri et al., 1976; Arias et al., 1977). Second, we considered the Cape Bojador succession an important deep-sea reference section for the extra-Mediterranean record during the time interval spanning the "salinity crisis" (see Cita in Smith, 1977). In our opinion, the biostratigraphy founded on calcareous nannofossils has the greatest resolution for the stratigraphic interval under discussion; we have nine datum levels available which are usable as zonal boundaries. In addition, we could utilize 15 magnetic polarity boundaries which can be independently calibrated to the nannofossil datums at other locations.

\section{Methods}

Approximately 200 samples are investigated micropaleontologically: one from each section from Core 19 (late Pliocene) to Core 69 (late Miocene). The material received was split in two groups; alternating samples were studied by R. M. at Pisa, and by I. R. and D. R. at Parma. The purpose of this subdivision was to obtain a better, more reliable, double checked stratigraphically controlled interval. Also, with two working groups, we could take advantage of their slightly different previous experience in regional stratigraphy.

One smear slide was obtained from each sample, from which observations were made on the optical polarizing microscope. A general range chart constructed from all the 200 samples is not included here, but it is at DSDP Headquarters at La Jolla and at the disposal of all interested scientists. Approximately 100 samples were investigated in a semiquantitative way, slightly modified after the procedures of Hay and Beaudry (1973). The results of this semiquantitative evaluation of the fossil occurrences are tabulated in Figure 1, where the criteria used for this evaluation are explained in detail.

\section{RESULTS}

From bottom to top, the interval investigated is here subdivided in two major parts: the first encompasses Core 69 to Section 57-4, the second from Section 57-1 to Core 19. 


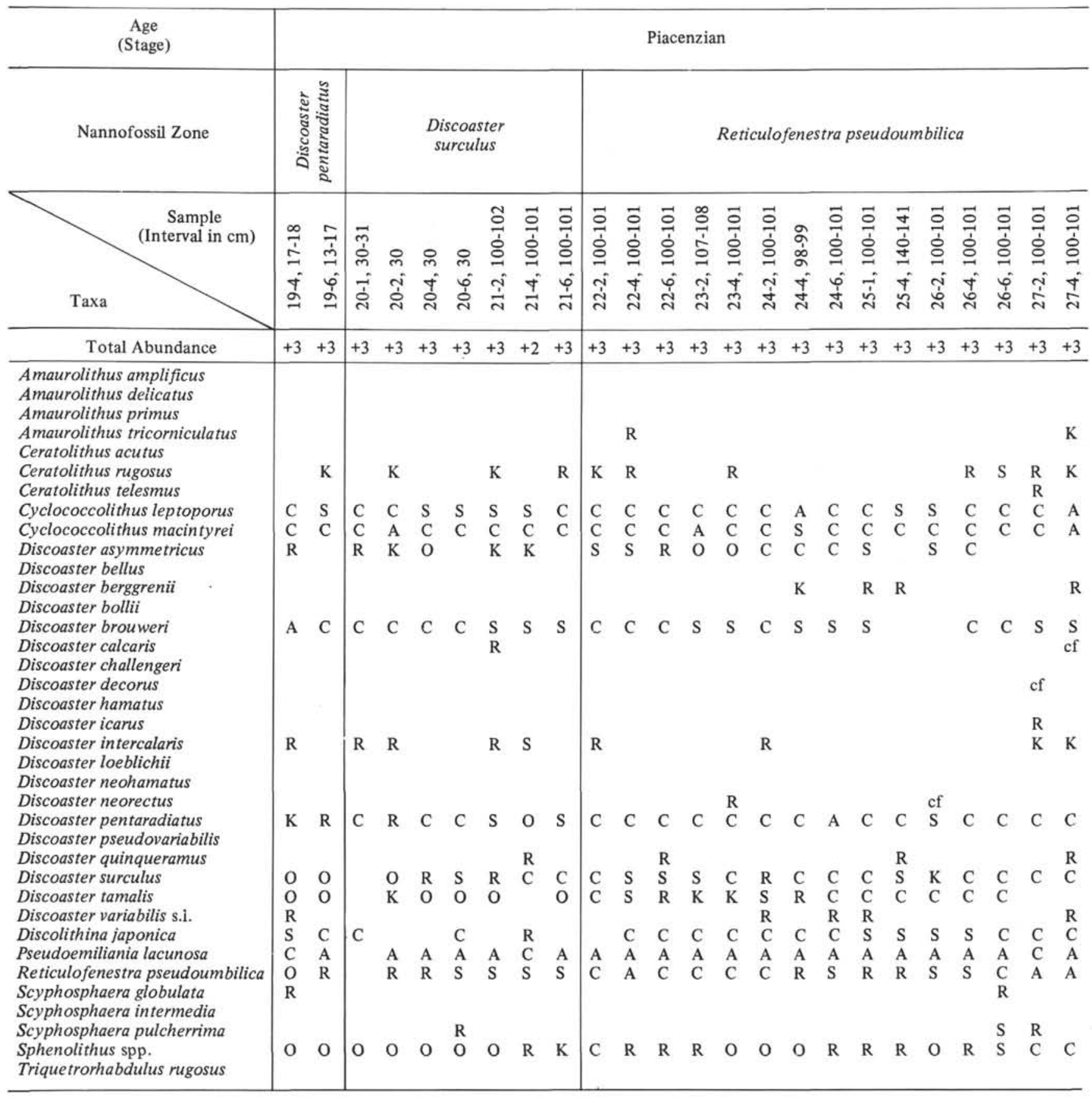

Figure 1. Distribution of calcareous nannofossil species in selected samples from Samples 57-1, 100-101 cm to 19-4, $17-18 \mathrm{~cm}$ of DSDP Hole 397. The symbols for total abundance are as follows: +3 indicates more than 30 specimens were observed in a field at 1200. + 2 that from 25 to 30 were counted in a field at 1200 . The relative abundances are as follows: $A>1$ specimen per field, $1200 \times ; C 1$ specimen per 1-10 fields, $1200 \times ; S$ a few specimens in 10 fields, $1200 \times ; R<1$ specimen in 10 fields, $1200 \times ; K 1$ specimen after a long search, 0 species looked for, but not recorded.

\section{Late Miocene Pre- and Synslump Interval (Core 69 to Section 57-4)}

Three parts are recognizable in this interval as follows:

1) Lower interval (Cores 69 through 66). Normal, hemipelagic sediments prevail, however slumped layers were recorded at various levels. Since samples from these lower cores were taken after the cruise, particular attention was given to their avoidance.

2) Intermediate interval (Core 65 through Section 61-6). Normal, hemipelagic sediments throughout.

3) Upper interval (Sections 61-5 through 57-4). Slumps are frequent in this interval, and several samples were taken from disturbed, contorted layers. Some of them (not all) yielded nannofossil assemblages 


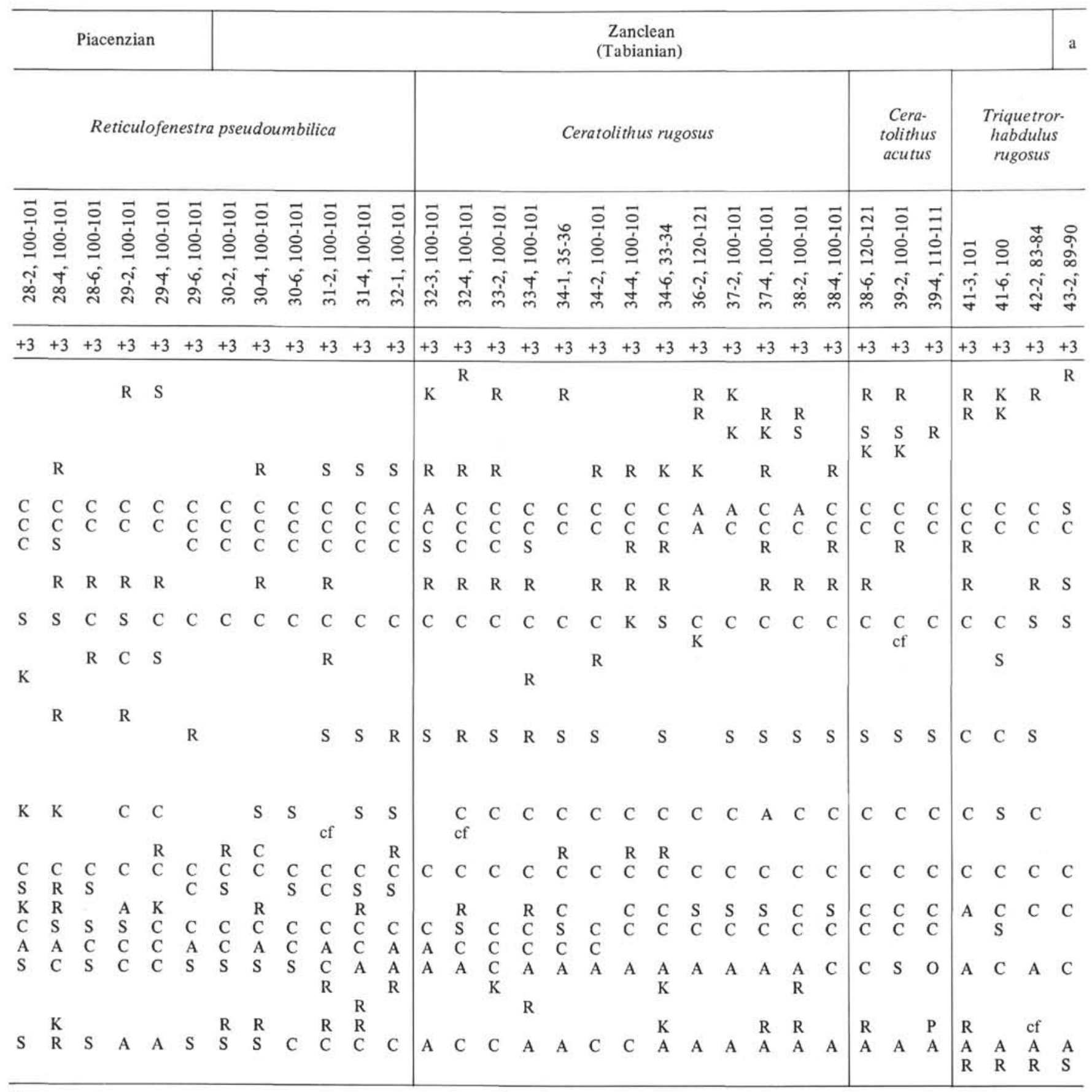

\section{${ }^{\mathrm{a}}$ Messinian.}

Figure 1. (Continued).

which are older than those from underlying beds (see Figure 2).

Generally speaking, calcareous nannofissil assemblages are rich, abundant, and well diversified. Evidence of dissolution at depth is recorded in planktonic foraminiferal assemblages. Nannofossils are poorly preserved, with etching and overgrowth common and occasionally hampering the identification of Discoasters at the species level.

Most of the interval under discussion is referred to as the Discoaster hamatus Zone of Bukry (1973a, 1975a), whose definition matches that of Zone NN 9 of the standard zonation (Martini, 1971). The zonal boundary between the $D$. hamatus and $D$. neohama$t^{t} s^{l}$ zones is here located at the base of Core 62. This zonal boundary falls in the intermediate intervl. According to Bukry (1973b), the D. hamatus/D. neohamatus boundary is defined by the last occurrence of Discoaster hamatus. It is necessary to clarify the presence of the zonal taxon higher in the section, i.e., in the

${ }^{1}$ The D. neohamatus Zone was originally defined as the interval from the last occurrence of $D$. hamatus to the first occurrence of $D$. berggrenii. 


\begin{tabular}{|c|c|c|c|c|c|c|c|c|c|c|c|c|c|c|c|c|c|}
\hline $\begin{array}{c}\text { Age } \\
\text { (Stage) }\end{array}$ & \multicolumn{7}{|c|}{ Messinian } & \multicolumn{10}{|c|}{ Tortonian } \\
\hline Nannofossil Zone & \multicolumn{10}{|c|}{ Amaurolithus primus } & \multicolumn{7}{|c|}{ Discoaster berggrenii } \\
\hline $\begin{array}{c}\text { Sample } \\
\text { (Interval in } \mathrm{cm})\end{array}$ & $\begin{array}{l}8 \\
\frac{8}{\alpha} \\
\text { व் } \\
\stackrel{+}{+}\end{array}$ & 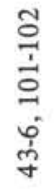 & 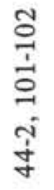 & $\begin{array}{l}-1 \\
\frac{0}{0} \\
0 \\
\dot{0} \\
\dot{y} \\
\dot{v}\end{array}$ & 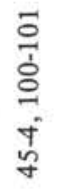 & $\begin{array}{l}\overline{0} \\
\frac{1}{0} \\
\stackrel{-}{-} \\
\overrightarrow{\dot{y}}\end{array}$ & 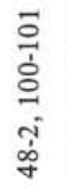 & 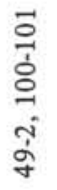 & 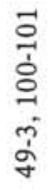 & $\begin{array}{l}\overrightarrow{0} \\
\dot{0} \\
0 \\
\dot{0} \\
\dot{0}\end{array}$ & 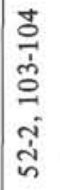 & $\begin{array}{l}\overrightarrow{0} \\
\frac{1}{0} \\
0 \\
\dot{n} \\
\text { n் }\end{array}$ & $\begin{array}{l}\overrightarrow{0} \\
\frac{1}{0} \\
0 \\
\dot{0} \\
\dot{1}\end{array}$ & $\begin{array}{l}\hat{a} \\
\dot{a} \\
\dot{+} \\
\dot{v}\end{array}$ & 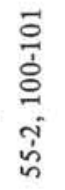 & $\begin{array}{l}\tilde{n} \\
0 \\
n \\
n \\
\text { in }\end{array}$ & $\begin{array}{l}\overrightarrow{0} \\
\frac{1}{0} \\
0 \\
\overrightarrow{1} \\
\text { in }\end{array}$ \\
\hline Total Abundance & +3 & +3 & +3 & +3 & +3 & +3 & +3 & +3 & +3 & +3 & +3 & +3 & +3 & +3 & +3 & +3 & +3 \\
\hline $\begin{array}{l}\text { Amaurolithus amplificus } \\
\text { Amaurolithus delicatus } \\
\text { Amaurolithus primus } \\
\text { Amaurolithus tricorniculatus } \\
\text { Ceratolithus acutus } \\
\text { Ceratolithus rugosus } \\
\text { Ceratolithus telesmus }\end{array}$ & $\begin{array}{l}\mathrm{R} \\
\mathrm{R}\end{array}$ & $\mathrm{R}$ & $\begin{array}{l}\mathrm{R} \\
\mathrm{R}\end{array}$ & $\begin{array}{l}\mathrm{R} \\
\mathrm{R}\end{array}$ & $\begin{array}{l}\mathrm{S} \\
\mathrm{S}\end{array}$ & $\mathrm{R}$ & $\begin{array}{l}\mathrm{R} \\
\mathrm{R}\end{array}$ & $\begin{array}{l}\mathrm{R} \\
\mathrm{R}\end{array}$ & $\begin{array}{l}\mathrm{R} \\
\mathrm{R}\end{array}$ & & & & & & & & \\
\hline Cyclococcolithus leptoporus & C & $\mathrm{C}$ & $\mathrm{C}$ & $\mathrm{C}$ & $\mathrm{S}$ & $\mathrm{C}$ & C & $\mathrm{S}$ & $\mathrm{C}$ & $\mathrm{C}$ & C & C & $\mathrm{C}$ & C & $\mathrm{C}$ & $\mathrm{C}$ & $\mathrm{C}$ \\
\hline $\begin{array}{l}\text { Cyclococcolithus macintyrei } \\
\text { Discoaster asymmetricus } \\
\text { Discoaster bellus }\end{array}$ & C & $\mathrm{C}$ & $\mathrm{S}$ & $\mathrm{S}$ & $\begin{array}{l}\mathrm{C} \\
\mathrm{R}\end{array}$ & $\mathrm{S}$ & $\begin{array}{l}\mathrm{C} \\
\mathrm{R}\end{array}$ & $\mathrm{C}$ & $\mathrm{C}$ & $\begin{array}{l}\mathrm{S} \\
\mathrm{R}\end{array}$ & $\mathrm{S}$ & S & $\mathrm{C}$ & $\mathrm{S}$ & $\begin{array}{l}\mathrm{C} \\
\mathrm{R}\end{array}$ & $\mathrm{C}$ & $\begin{array}{l}\mathrm{C} \\
\mathrm{R}\end{array}$ \\
\hline $\begin{array}{l}\text { Discoaster berggrenii } \\
\text { Discoaster bollii }\end{array}$ & S & $\mathrm{C}$ & $\mathrm{C}$ & $\mathrm{C}$ & $\mathrm{C}$ & $\mathrm{C}$ & $\mathrm{C}$ & $\mathrm{C}$ & $\mathrm{C}$ & $\mathrm{C}$ & $\mathrm{C}$ & $\mathrm{C}$ & $\mathrm{C}$ & $\begin{array}{l}\mathrm{C} \\
\mathrm{cf}\end{array}$ & $\begin{array}{l}\mathrm{C} \\
\mathrm{K}\end{array}$ & $\mathrm{R}$ & $\mathrm{R}$ \\
\hline $\begin{array}{l}\text { Discoaster brouweri } \\
\text { Discoaster calcaris } \\
\text { Discoaster challengeri } \\
\text { Discoaster decorus } \\
\text { Discoaster hamatus }\end{array}$ & $\mathrm{C}$ & $\mathrm{C}$ & $\mathrm{C}$ & $\mathrm{S}$ & $\mathrm{R}$ & & $\mathrm{C}$ & $\begin{array}{l}\mathrm{C} \\
\mathrm{cf} \\
\mathrm{cf}\end{array}$ & $\mathrm{R}$ & $\mathrm{C}$ & C & ef & $\mathrm{R}$ & $\mathrm{C}$ & $\mathrm{C}$ & $\begin{array}{l}\mathrm{C} \\
\mathrm{cf}\end{array}$ & $\begin{array}{l}\mathrm{C} \\
\mathrm{R} \\
\mathrm{R}\end{array}$ \\
\hline $\begin{array}{l}\text { Discoaster icarus } \\
\text { Discoaster intercalaris }\end{array}$ & $\mathrm{S}$ & $\mathrm{C}$ & $\mathrm{S}$ & $\mathrm{C}$ & $\mathrm{S}$ & $\mathrm{S}$ & $\mathrm{S}$ & $\mathrm{S}$ & $\mathrm{K}$ & & cf & $\begin{array}{l}\mathrm{R} \\
\mathrm{R}\end{array}$ & $\begin{array}{l}\mathrm{R} \\
\mathrm{R}\end{array}$ & $\begin{array}{l}\mathrm{R} \\
\mathrm{R}\end{array}$ & & $\mathrm{S}$ & $\begin{array}{l}\mathrm{C} \\
\mathrm{R}\end{array}$ \\
\hline $\begin{array}{l}\text { Discoaster loeblichii } \\
\text { Discoaster neohamatus } \\
\text { Discoaster neorectus }\end{array}$ & & & & & & & & & & & & & $\mathrm{C}$ & $\mathrm{C}$ & $\begin{array}{l}\mathrm{C} \\
\mathrm{S}\end{array}$ & $\mathrm{R}$ & $\begin{array}{l}\mathrm{R} \\
\mathrm{cf}\end{array}$ \\
\hline $\begin{array}{l}\text { Discoaster pentaradiatus } \\
\text { Discoaster pseudovariabilis }\end{array}$ & $\begin{array}{l}\mathrm{S} \\
\mathrm{R}\end{array}$ & $\mathrm{S}$ & $\mathrm{C}$ & $\mathrm{C}$ & $\mathrm{C}$ & $\mathrm{C}$ & $\begin{array}{l}\mathrm{C} \\
\mathrm{R}\end{array}$ & $\mathrm{S}$ & $\mathrm{C}$ & $\mathrm{C}$ & & $\mathrm{S}$ & $\mathrm{S}$ & $\mathrm{S}$ & $\mathrm{C}$ & $\mathrm{C}$ & $\mathrm{C}$ \\
\hline Discoaster quinqueramus & $\mathrm{R}$ & $\mathrm{R}$ & $\mathrm{S}$ & $\mathrm{S}$ & $\mathrm{C}$ & $\mathrm{C}$ & $\mathrm{C}$ & $\mathrm{C}$ & $\mathrm{C}$ & $\mathrm{C}$ & $\mathrm{S}$ & $\mathrm{S}$ & $\mathrm{R}$ & $\mathrm{C}$ & $\mathrm{S}$ & & \\
\hline $\begin{array}{l}\text { Discoaster surculus } \\
\text { Discoaster tamalis }\end{array}$ & $\mathrm{C}$ & $\mathrm{C}$ & $S$ & $\mathrm{C}$ & $S$ & $\begin{array}{l}\mathrm{C} \\
\mathrm{R}\end{array}$ & $\mathrm{S}$ & $\mathrm{R}$ & C & $\mathrm{C}$ & $\mathrm{R}$ & $S$ & $\mathrm{O}$ & $\mathrm{O}$ & K & & \\
\hline Discoaster variabilis s.1. & $\mathrm{C}$ & $\mathrm{C}$ & $\mathrm{C}$ & $\mathrm{C}$ & $\mathrm{C}$ & $\mathrm{C}$ & & $\mathrm{C}$ & $\mathrm{C}$ & $\mathrm{C}$ & $\mathrm{C}$ & $\mathrm{C}$ & $\mathrm{C}$ & $\mathrm{C}$ & $\mathrm{C}$ & & $\mathrm{C}$ \\
\hline $\begin{array}{l}\text { Discolithina japonica } \\
\text { Pseudoemiliania lacunosa }\end{array}$ & S & $\mathrm{S}$ & $\mathrm{S}$ & $\mathrm{S}$ & & $\mathrm{S}$ & & $\mathrm{R}$ & $\mathrm{C}$ & $\mathrm{S}$ & & $\mathrm{S}$ & & $\mathrm{S}$ & & & $\mathrm{R}$ \\
\hline $\begin{array}{l}\text { Reticulofenestra pseudoumbilica } \\
\text { Scyphosphaera globulata } \\
\text { Scyphosphaera intermedia } \\
\text { Scyphosphaera pulcherrima }\end{array}$ & $\mathrm{C}$ & $\mathrm{C}$ & A & $\mathrm{C}$ & $\begin{array}{l}\mathrm{C} \\
\mathrm{K} \\
\mathrm{K}\end{array}$ & $\mathrm{C}$ & & A & $\begin{array}{l}\text { A } \\
\text { R } \\
\text { S }\end{array}$ & $\mathrm{C}$ & $\mathrm{O}$ & A & $\mathrm{R}$ & $\mathrm{R}$ & $\mathrm{S}$ & $\mathrm{C}$ & $\mathrm{S}$ \\
\hline Sphenolithus spp. & C & $\mathrm{C}$ & A & A & $\mathrm{A}$ & A & $\mathrm{A}$ & A & A & A & A & A & A & A & A & A & $\mathrm{C}$ \\
\hline Triquetrorhabdulus rugosus & $\mathbf{R}$ & $\mathrm{S}$ & $\mathrm{R}$ & $\mathrm{R}$ & $\mathrm{R}$ & & $\mathrm{R}$ & & & $\mathrm{R}$ & & $\mathrm{S}$ & $\mathrm{C}$ & $\mathrm{C}$ & $\mathrm{S}$ & & $\mathrm{S}$ \\
\hline
\end{tabular}

Figure 1. (Continued).

upper interval with slumps (such as Samples 61-5, 101 $\mathrm{cm}$; $61-3,101 \mathrm{~cm}$; and $60-5,101 \mathrm{~cm}$ ), and as far uphole as Section 58-1. The nominal taxon is recorded in most of the samples investigated, both those from the slumps and from the "normal" sediment. Therefore, it is questionable whether the specimens are reworked, or whether the entire upper interval is disturbed, despite sedimentological evidence to the contrary. As an alternative, one could question our location of the Discoaster hamatus /D. neohamatus zonal boundary.

The experience by one of us (R.M.) on several sections measured in the Mediterranean, including the stratotype of the Tortonian stage, facilitated the identi- fication of two biostratigraphic events which can be used to correctly locate the $D$. hamatus $/ D$. neohamatus zonal boundary, as follows:

1) the FAD of $D$. pentaradiatus recorded by Bukry (1973a, p. 693) within the D. neohamatus Zone, slightly predates the LAD of D. hamatus (Mazzei, 1977).

2) the FAD of Globigerinoides obliquus extremus postdates the LAD of D. hamatus (Martini, 1975; Mazzei, 1977).

The former biostratigraphic event was recorded in Section 63-1 (see Figure 2), the latter in Section 60-2 (see Salvatorini and $\mathrm{Cita}$, this volume). As a conse- 


\begin{tabular}{|c|c|c|c|c|c|c|c|c|c|c|c|c|c|c|c|c|c|c|c|c|c|c|c|}
\hline CHRONOSTRATIGRAPHY & \multicolumn{23}{|c|}{ TORTONIAN } \\
\hline BIOSTRATIGRAPHY & \multicolumn{12}{|c|}{ DISCOASTER NEOHAMATUS } & \multicolumn{11}{|c|}{ DISCOASTER HAMATUS } \\
\hline CORE & \multicolumn{2}{|c|}{57} & \multicolumn{2}{|c|}{58} & \multicolumn{3}{|c|}{60} & \multicolumn{2}{|c|}{61} & \multicolumn{3}{|c|}{62} & 63 & \multicolumn{2}{|c|}{64} & \multicolumn{2}{|c|}{65} & \multicolumn{2}{|c|}{66} & \multirow{2}{*}{$\frac{67}{1}$} & \multirow{2}{*}{$\begin{array}{c}68 \\
2\end{array}$} & \multicolumn{2}{|c|}{69} \\
\hline SECTION & 3 & 5 & 1 & 3 & 1 & 3 & 5 & 3 & 5 & 1 & 3 & 5 & 1 & 1 & 3 & 2 & 4 & 2 & 5 & & & 1 & 4 \\
\hline INTERVAL (cm) & $\begin{array}{l}47 . \\
48 \\
\end{array}$ & $\begin{array}{l}69- \\
70 \\
\end{array}$ & $\begin{array}{l}100 \\
101 \\
\end{array}$ & $\begin{array}{l}87 . \\
89 \\
\end{array}$ & \begin{tabular}{|l|}
104 \\
105 \\
\end{tabular} & 100 & $\begin{array}{l}90- \\
91\end{array}$ & $\begin{array}{l}110- \\
111 \\
\end{array}$ & \begin{tabular}{|l|}
100 \\
101 \\
\end{tabular} & \begin{tabular}{|l|}
$101-$ \\
102 \\
\end{tabular} & \begin{tabular}{|l|}
100 \\
102 \\
\end{tabular} & $\begin{array}{l}78 . \\
79\end{array}$ & $\begin{array}{l}92- \\
93 \\
\end{array}$ & $\begin{array}{l}6- \\
7 \\
\end{array}$ & \begin{tabular}{|l|}
$113-$ \\
114 \\
\end{tabular} & \begin{tabular}{|l|}
$86-$ \\
87 \\
\end{tabular} & $\begin{array}{l}32 . \\
34 \\
\end{array}$ & $\begin{array}{l}42- \\
43 \\
\end{array}$ & \begin{tabular}{|l|}
32. \\
34 \\
\end{tabular} & $\begin{array}{l}14 . \\
15 \\
\end{array}$ & $\begin{array}{l}61- \\
62 \\
\end{array}$ & $\begin{array}{l}45- \\
46 \\
\end{array}$ & $\begin{array}{l}21 . \\
22 \\
\end{array}$ \\
\hline
\end{tabular}

Catinaster calyculus Catinaster coalitus Coccolithus pelagicus Cyclococcolithus leptoporus Cyclococcolithus macintyrei Discoaster hamatus Discoaster bellus Discoaster prepentaradiatus Discoaster pentaradiatus Discoaster quinqueramus Discoaster neohamatus Discoaster calcaris Discoaster loeblichii

Discoaster bollii

Discoaster exilis Discoaster brouweri Discoaster stellulus Discoaster challengeri Discoaster pseudovariabilis Discoaster variabilis s. I. Discoaster perclarus Discoaster intercalaris Discoaster icarus

Discoaster subsurculus Discoaster tamalis Discoaster asymmetricus Discoaster braarudii Discoaster aulakos Discoaster kugleri Discoaster signus Discoaster deflandrei Lithostromation perdurum Discolithina japonica Discolithina multipora Scyphosphaera pulcherrima Scyphosphaera halldali Scyphosphaera tubifera Scyphosphaera apsteini Helicopontosphaera kamptneri Reticulofenestra pseudoumbilica Rhabdosphaera procera Sphenolithus abies Sphenolithus neoabies Sphenolithus spp.

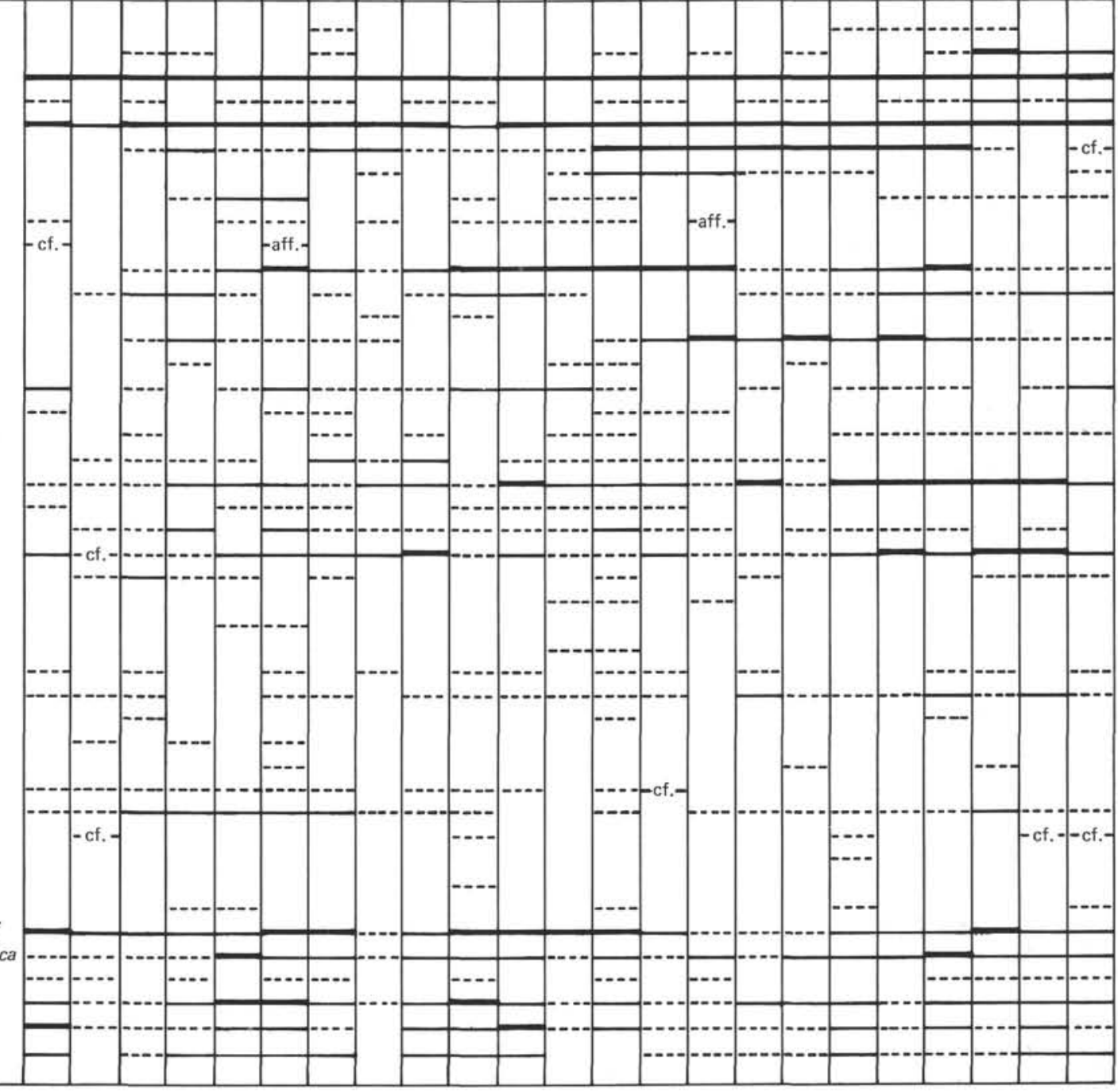

LEGEND: abundance/distribution abundant common

-.-. few or rare

Figure 2. Distribution of calcareous nannofossil species in selected samples from Samples 69-4, 21-22 cm to 57-3, 47-48 cm of DSDP Hole 397.

quence, the location of the $D$. hamatus/D. neohamatus zonal boundary at the base of Core 62 is consistent with other findings and coincides with a strong decrease in abundance of $D$. hamatus, if not with the total disapperance of the taxon.

\section{Late Miocene To Late Pliocene Normal Succession (Section 57-3 to Core 19)}

Figure 1 shows the distribution of the age-diagnostic taxa from this interval. The zonation adopted here in- corporates a number of zones previously defined by Hay et al. )1967), Gartner (1969), Martini (1971), Bukry (1973d, 1975b), and Roth (1973, 1974); see Figure 3. From bottom to top, the following zones could be identified:

Discoaster berggrenii Zone: defined as the interval from the FAD of the nominal taxon to the FAD of Amaurolithus primus, this biozone encompasses Samples $57-1,101 \mathrm{~cm}$ to $52-1,104 \mathrm{~cm}$, with a total thickness of approximately 48 meters. The most significant taxa associated with the zonal marker are $D$. 


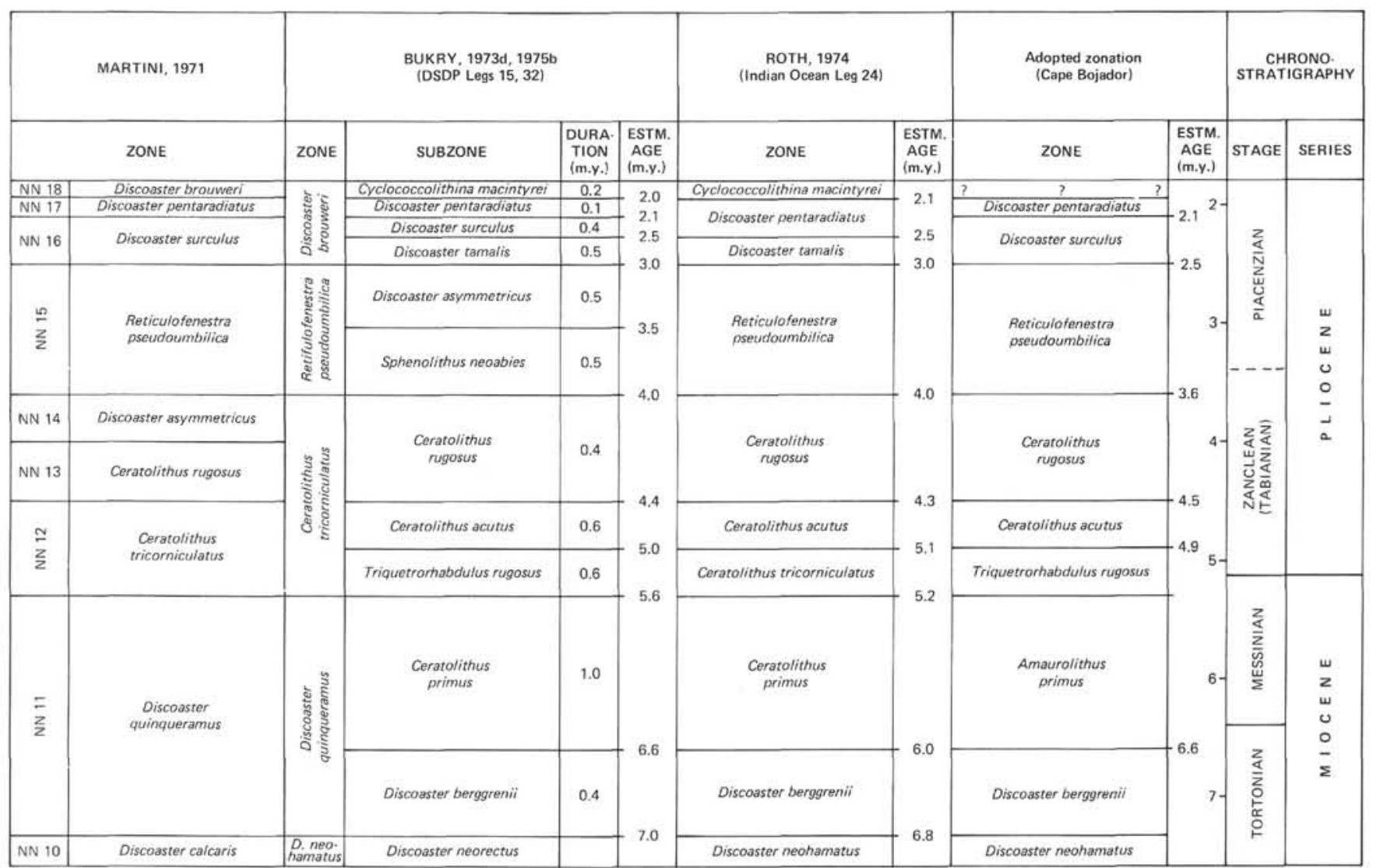

Figure 3. Correlation of the biozonation followed in the present report (column to the right) with other zonations previously established on deep-sea sediments. The estimated absolute age of the zonal boundaries of Bukry's and Roth's subdivisions are also indicated, and discussed in the text.

quinqueramus (less abundant than $D$. berggrenii), $D$. surculus (first recorded within this biozone), $D$. pentaradiatus, and Triquetrorhabdulus rugosus. This zone corresponds to and can be correlated with the lower part of Zone NN 11 (D. quinqueramus Zone) of Martini's standard zonation, to the $D$. berggrenii Zone of Roth (1973), and to the $D$. berggrenii Subzone of Bukry (1973d).

Amaurolithus primus Zone: the interval from the FAD of the nominal taxon to the LAD of Discoaster quinqueramus. The taxa which characterize the present zone are the same as in the underlying zone, plus nonbirefringent Ceratoliths ( $A$. primus, A. delicatus, A. amplificus). Though Ceratoliths are not particularly abundant in the Cape Bojador drill site, their presence is considered meaningful. Reference is made to the section on reworking for the location of the $D$. quinqueramus LAD. A. amplificus becomes extinct within this biozone, which encompasses Samples $50-1,101 \mathrm{~cm}$ to $43-4,100 \mathrm{~cm}$, for a total thickness of approximately 70 meters. The correspondence between this biozone and others in indicated in Figure 3.

Triquetrorhabdulus rugosus Zone: the interval from the LAD of $D$. quinqueramus to the LAD of the nominal taxon. It includes Samples 43-2, $90 \mathrm{~cm}$ to $41-3,101$ $\mathrm{cm}$, for a total thickness of approximately 16.5 meters. The floral assemblage is similar to those of the underly- ing zone, with the exception of $D$. quinqueramus and $D$. berggrenii, which are here rare and interpreted as being reworked (see below). Occasional specimens of $A$. tricorniculatus and Discoaster asymmetricus are also recorded. Reference is made to Figure 3 for correlations.

Ceratolithus acutus Zone: the interval from the LAD of $T$. rugosus to the FAD of Ceratolithus rugosus. It encompasses Samples 39-5, $91 \mathrm{~cm}$ to $38-5,101 \mathrm{~cm}$, for a total thickness of approximately 10 meters. This short duration biozone has been defined by Bukry (1973d). as a sub-zone, and also used by Roth (1973). According to both authors, it is characterized by the occurrence of Ceratolithus acutus which is only occasionally recorded at DSDP Site 397. Following Bukry (1973d), we based the identification of this biostratigraphic interval on the extinction of Triquetrorhabdulus rugosus, a taxon which is consistently recorded in the Cape Bojador drill site, though never abundant. The two biostratigraphic events (LAD of T. rugosus and FAD of $C$. acutus) could be slightly diachronous, however the difference is very small (Bukry, 1973d, p. 694).

Ceratolithus rugosus Zone: the interval from the FAD of $C$. rugosus to the LAD of Amaurolithus delicatus. It encompasses Samples 38-4, $101 \mathrm{~cm}$ to 32-3, 101 $\mathrm{cm}$, for a total thickness of approximately 55 meters. Within this biozone, we can see the consecutive disap- 
pearance of the three species of non-birefringent Ceratoliths Amaurolithus tricorniculatus, A. primus, and A. delicatus. It is worthwhile mentioning that the forms which we refer to $C$. rugosus occasionally display highly evolved characters, similar to those recorded in C. cristatus. The first occurrence of primitive forms of Pseudoemiliania lacunosa is recorded in the upper part of this interval. Discoaster asymmetricus, which is consistently recorded (though rare) throughout the present biozone, increases in abundance in the following one.

Reticulofenestra pseudoumbilica Zone: the interval from the LAD of Amaurolithus delicatus to the LAD of the nominal taxon. It includes Samples $32-2,101 \mathrm{~cm}$ to $22-2,101 \mathrm{~cm}$, with a total thickness of 95.0 meters, although scattered occurrences of $R$. pseudoumbilica are found upwards to Core 19. Among the taxa which characterize this interval are Discoaster tamalis and $D$. asymmetricus (which are first here recorded with a certain degree of abundance), Pseudoemiliania lacunosa (well-represented with typical forms), and Ceratolithus rugosus. C. telesmus is also recorded here. Reference is made to Figure 3 for the correlation and correspondence with other zonation used in the literature.

Discoaster surculus Zone: the interval from the LAD of Reticuloferestra pseudoumbilica to the LAD of the nominal taxon. It corresponds to Sample $22-1,101 \mathrm{~cm}$ to $20-1,31 \mathrm{~cm}$, with a total thickness of approximately 20 meters. Within this zone, Discoaster asymmetricus and $D$. tamalis, which were well represented in the underlying zone, are again rare. This interval corresponds to Zone NN 16 of the standard zonation; to the lower part of the Discoaster brouweri Zone of Bukry (1973d), i.e., D. tamalis and D. surculus subzones; and to most of the D. tamalis Zone of Roth (1973).

Discoaster pentaradiatus Zone: the interval from the LAD of $D$. surculus to the LAD of the nominal taxon. Only Core 19, with a total thickness of 9.5 meters, is referable to this zone, which is known as the shortest in duration of Martini's zonation (NN 17).

\section{DISCUSSION}

\section{The Problem of Reworking}

In a continental rise setting, one may expect to encounter reworked strata. In the late Neogene succession investigated here, however, reworking is not important, especially in the upper part of the section above the slump interval. Between Core 69 and Section $57-3$, we noticed the effects of slumping and reworking interacting. Nannoconus from the Early Cretaceous are recorded frequently, but never abundant; Discoaster saipanensis from the Eocene was noticed in Core 68 and Section 63-1; Isthmolithus recurvus, from the Eocene, is present in Section 58-2; whereas Sphenolithus heteromorphus, from the early and middle Miocene, is found in several samples.

Between Section 57-3 and Core 19, where hemipelagic sediments were recorded, reworking is slight; however, we noticed some reappearances of characteristic taxa above their LAD. In such cases, the location of the LAD in the stratigraphic succession could be questioned. We therefore looked for other evidence suggestive of reworking, such as (a) the occurrence of planktonic foraminiferal species interpreted as reworked in the same interval, and (b) of terrigenous input in abnormal abundances. In other words, we tried to discriminate the biostratigraphic "signal" provided by the extinction of characteristic taxa from the "noise" induced by reworking.

From bottom to top, the major discrepancies between LAD and higher (scattered) occurrences concern the following taxa:

Discoaster berggrenii: LAD in Section 43-2, scattered occurrence up to Core 19.

Discoaster quinqueramus: LAD in Section 43-4, very scattered occurrence up to Section 22-2, with a limited peak of abundance in Section 30-4.

Amaurolithus spp.: LAD in Section 32-3, higher occurrences (very scattered) up to Section 27-1 (A. delicatus), and up to Section 22-2 (A. tricorniculatus).

Reticulofenestra pseudoumbilica: LAD in Section 22-2, scattered occurrence up to Core 19.

Sphenolithus spp.: strong decrease in abundance in Section 26-3, and a general upwards decrease in abundance.

\section{Paleoecological Indications of the Nannofossil Assemblages}

Site DSDP 397, about 90 kilometers from the African coast at $26^{\circ} \mathrm{N}$, is located in an area of upwelling and active boundary currents (Canary Current). Are these oceanographic conditions affecting the composition of the calcareous phytoplankton? Is there any indication in the fossil assemblages that these conditions changed through time? The following observations concern the post-slump interval, i.e., Cores 57 (partim) to 19 .

The nannofossil assemblages generally are rich and well-diversified throughout the upper Miocene to upper Pliocene. The only exception is represented by the group of Ceratoliths, which only occasionally represent a significant component of the assemblage. Ceratoliths are open ocean forms; therefore, it is not surprising that they are poorly represented in a continental rise setting.

The genus Scyphosphaera is represented in most samples, however the number of specimens is low. According to the majority of authors (e.g., Rade, 1976), this genus prefers shelf areas and is common in tropical and subtropical water masses. Its absence or scattered occurrence suggests the persistence of cool boundary currents in this area. It is worthwhile mentioning that the genus Scyphosphaera is much better represented in the Mediterranean area, both in the late Neogene fossil record (Stradner, 1973) and in the present-day Tyrrhenian Sea (Cati and Borsetti, 1970b). The implication is that the Mediterranean waters were relatively warmer than northeastern Atlantic water at lower latitudes in the time interval under discussion. This deduction is supported in part by the qualitative and quantitative distribution of planktonic foraminifers, with special reference to the late Pliocene. It is in good agreement 
with the circulation pattern postulated by Cifelli for the late Pliocene.

Not recorded at all in any of the 200 samples investigated is the opportunistic genus Braarudosphaera ("discoaster form" sensu Fischer and Arthur, 1976). Its absence suggests normal marine conditions, without dilution by continental waters, and an absence of stress conditions.

\section{Correlation With Planktonic Foraminferal Datum Planes}

Figure 4 shows the relative position of key species of calcareous plankton, as recorded in the interval investigated at the Cape Bojador drill site. Reference is made to a previous section of this paper for a discussion of the calcareous nannofossils. Although over 40 species of planktonic foraminifers have been identified, only a few are plotted here. They have been carefully selected excluding some typically tropical forms (such as Globorotalia tumida, Pulleniatina spp., and the Globorotalia menardii plexus), because of their sensitivity to climatic changes, to dissolution at depth, or for their scattered occurrence. A range chart encompassing Cores 57 to 32 is included in the paper by Salvatorini and Cita (this volume) to which reference is made; no range chart is provided for the cores above this interval. Seven foraminiferal datum planes could be recognized in the interval encompassing Section 57-3 to Core 19. From bottom to top, they are as follows:

1) Coiling change of Globorotalia acostanensis from sinistral (below) to dextral (above) from Sections 47-3 to $47-2$, at approximately 440 meters sub-bottom. An identical coiling change predating the FAD of $G$. margaritae has been recognized by Saito et al. (1975) in the equatorial Pacific (Core RC 12-66), by Bossio et al. (1976) in the Bou Regreg section of Morocco, and in the Mediterranean (see Stainforth et al., 1975, fig. 25, p. 105 and p. 333; Zachariasse, 1975).

2) FAD of Globorotalia margaritae recorded in Section $45-1$ at approximately 418 meters sub-bottom. It is an evolutionary first occurrence, as discussed in Salvatorini and Cita (this volume), and it is recorded a few meters beneath the LAD of Discoaster quinqueramus. The relative position of the two biostratigraphic events is similar to that recorded in Core RC 12-66 (Equatorial Pacific) by Gartner (1973) and by Saito et al. (1975). The same relative position of taxa has also been recorded in the Bou Regreg section of Morocco (Bossio et al., 1976).

3) FAD of Globorotolia puncticulata recorded in Sample $35-2$, CC, possibly at 323 meters sub-bottom (could be also $332 \mathrm{~m}$ sub-bottom, due to incomplete core recovery). The FAD of $G$. puncticulata is considered an excellent biostratigraphic datum plane in the Mediterranean region, and is recorded very close to the FAD of Ceratolithus rugosus. In equatorial Pacific piston cores (RC 1-66 and V 24-59), the entrance of $C$. rugosus predates that of $G$. puncticulata (see Gartner, 1973; versus Saito et al., 1975); the same relative position is recorded in the Capo Rossello section (Zanclean stratotype, see Cita and Gartner, 1973; Gartner, 1977).
At DSDP Site 132, G. puncticulata is first recorded slightly beneath the first appearance of $C$. rugosus (Stradner in Ryan, Hsü, et al., 1973; Bukry, 1973c; see also discussion in Ryan et al., 1974).

4) LAD of Globorotalia margaritae recorded in Section 29-1, at approximately 266 meters sub-bottom. This datum plane is weakly defined in this hole, since the taxon is also recorded higher in the section, where its occurrence is interpreted as due to reworking. The distribution of the taxon is consistent and continuous up to Core 32. The occurrence is scattered from this point uphole; this taxon is consistently absent from all the samples investigated from Core 28. No marked contradiction versus the nannofossil biohorizons is recorded: the extinction of $G$. margaritae falls within the lower part of the Reticulofenestra pseudoumbilica Zone.

5) LAD of Sphaeroidinellopsis spp. recorded in Section 25-1, at 228 meters sub-bottom. The LAD of Sphaeroidinellopsis spp. and of Globoquadrina altispira are recorded very close to one another at Site 397, as in other areas (see Hays et al., 1969; Saito et al., 1975; Cita, 1973b; Ryan et al., 1974). The relative position of this datum plane and of the zonal boundary between the Reticulofenestra pseudoumbilica and Discoaster surculus zones as recorded at Site 397 is consistent with what has been observed in the equatorial Pacific (Gartner, 1973, versus Saito et al., 1975) and in the Mediterranean area (Capo Rossello, see Cita and Gartner, 1973), where the LAD of Sphaeroidinellopsis predates the LAD of $R$. pseudoumbilica. In the Tyrrhenian Sea (Site 132, see Cita and Ryan, 1973), the two datum planes are virtually coincidental, as well as at Site 12 in the North Atlantic where the LAD of $R$. pseudoumbilica is recorded $75 \mathrm{~cm}$ beneath the LAD of Sphaeroidinellopsis.

6) LAD of Globigerinoides obliquus extremus recorded in Section 1 of Core 21, at approximately 190 meters sub-bottom. The relative position of this LAD versus the LAD of Discoaster surculus differs at Sites 397 and 132; in the latter, D. surculus disappears earlier than $G$. extremus, unlike at Cape Bojador. In both instances, the two biostratigraphic events are close to one another.

7) LAD of Globorotalia miocenica recorded in Section $19-1$, at 171 meters sub-bottom. The relative position of this datum level versus the nannofossil biostratigraphy is in good agreement with the recorded findings in the equatorial Pacific (Gartner, 1973; Saito et al., 1975).

\section{Correlation With Magnetic Reversals and With the Paleomagnetic Time Scale}

Fifteen polarity reversals are recognized in the interval encompassing Cores 57 to 19 . Some of these reversals can be correlated in a straightforward manner to an established geomagnetic polarity time scale (Hamilton, this volume), whereas others are not easily attributed to a definite event or epoch. These differences in the paleomagnetic record for the Cape Bojador drill site possibly are due to a combination of missing data 

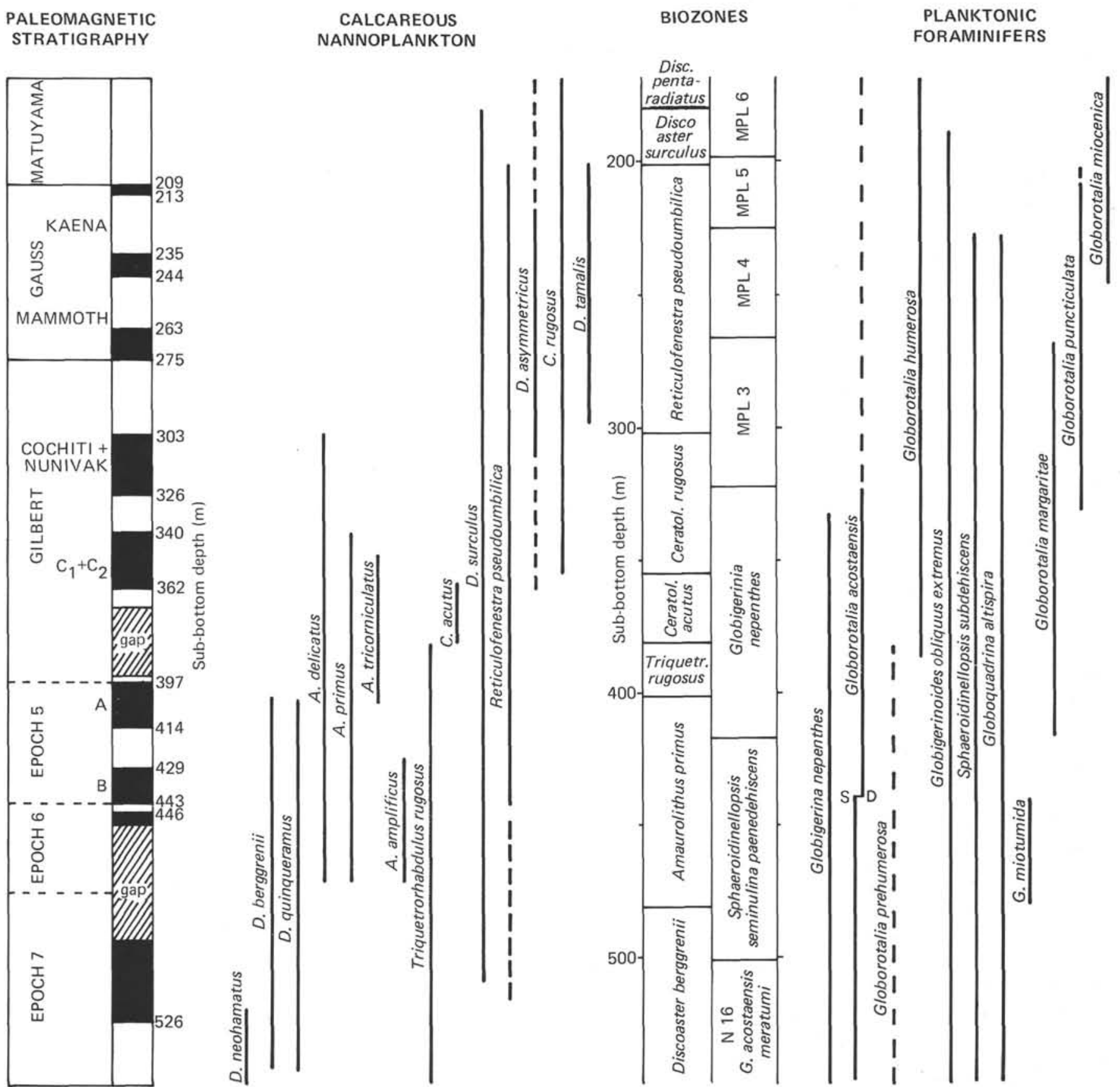

Figure 4. Paleomagnetic record of Cores 19-57, DSDP Site 397 (column to the left), distribution of selected calcareous nannofossils and planktonic foraminifers, and location of zonal boundaries.

(because of drill core disturbance, some intervals could not be sampled), coupled with difficulty in the recognition of absolute polarities in sediments with very low magnetic intensities.

Contrary to previous conventions, we will now discuss the section from top to bottom (see Figure 4).

1) The long interval with reversed polarity encompassing Cores 19 to 23 (209 m sub-bottom) corresponds to the lower part of the Matuyama Epoch. The paleomagnetic assignment has a good biostratigraphic support founded on both foraminifers and calcareous nannoplankton.
2) The interval from the top of Core 23 to the top of Core 30 (209 to $275 \mathrm{~m}$ sub-bottom), which should correspond to the Gauss Epoch, is more difficult to interpret. In fact, the normal polarity intervals which are recorded (respectively) in the topmost part and in the lowest part appear much shorter than usual. This paleomagnetic signature, if correct, could suggest (minor) hiatuses. Is there some supporting evidence in the stratigraphic record for the above assumption? All the planktonic foraminiferal biozones, and all those based on calcareous nannofossils recorded, or which should be recorded in this interval, are present at Site 397, 
with the exception of the Discoaster tamalis Zone of Bukry (1973d). This zone is defined as the interval from the LAD of $R$. pseudoumbilica to the LAD of Discoaster tamalis; the two taxa disapper at the same level at Site 397 (see Figure 4) in Section 22-2, or above the interval under discussion. In other words, if hiatuses do exist, they have a duration which is shorter than the duration of a biozone.

The relatively reduced thickness of Zone M P1 5 (of Cita, 1975b) in the Cape Bojador succession could be in agreement with a reduction related to a (small) hiatus above the extinction horizon of Sphaeroidinellopsis (Zone M P1 4/M P1 5 boundary), located at the base of Core 24. The location of this datum plane with reference to the paleomagnetic record is in good agreement at Site 397 and in the equatorial Pacific (Core RC 22-66, see Saito et al., 1975).

3) The underyling interval located between 290 and 397 meters sub-bottom is correlated to the Gilbert Epoch. Only two of the four normal events known to occur in this epoch could be recognized. It is suggested that the Nunivak and Cochiti events may be combined in the single normal interval. Similarly, $C_{1}$ and $C_{2}$ are not recognizable as split events.

The following biostratigraphic horizons, previously calibrated to the paleomagnetic record, are useful in deciphering this interval (always discussed from top to bottom): (a) LAD of Amaurolithus delicatus at the top of the Gilbert (see Gartner, 1973). (b) FAD of Globorotalia puncticulata at the base of a normal interval (Cochiti/Nunivak?). This biostratigraphic event is calibrated at the $C_{1} / B$ event of the Gilbert Epoch according to Ryan et al. (1974). The somewhat delayed entrance of the taxon at Site 397 could be related to the poor core recovery in this particular part of the section. (c) FAD of Ceratolithus rugosus at the base of the normal event $\left(\mathrm{C}_{1}\right)$ $\left.\mathrm{C}_{2}\right)$ in a normal interval $\left(\mathrm{C}_{2}\right.$ according to Gartner, 1973; Ryan et al., 1974).

4) The interval, with prevailing normal magnetization, between 397 and 443 meters sub-bottom, is referred to Epoch 5. This interpretation is well supported by biostratigraphic data, in particular (a) overlap of Discoaster quinqueramus and of Globorotalia margaritae from Sections 43-4 to 45-1. (b) FAD of Globorotalia margaritae in the reversed interval of Core 45 . This paleomagnetic calibration is in perfect agreement with that recorded by Saito (in Ryan et al., 1974, see also Saito et al., 1975) in Core RC 12-66 from the equatorial Pacific. (c) coiling change of $G$. acostaensis from sinistral up to Section 47-3, to dextral uphole from Section 47-2. This biostratigraphic event was calibrated in the equatorial Pacific piston Core RC 12-66 in the lowermost part of Epoch 5, or at exactly the same position as at Site 397.

5) The interval from the paleomagnetic reversal recorded at 443 meters sub-bottom to an unidentified level at approximately 465 meters sub-bottom (gap in the paleomagnetic record) corresponding to the FAD of Amaurolithus delicatus is tentatively referred to Epoch 6. The biostratigraphic evidence supporting this assignment is the FAD of $A$. delicatus (i.e., Ceratolithus tricorniculatus Auctorum), considered as occurring at the top of Epoch 7 (Ryan et al., 1974) and recorded in Core 49, Section 3, at approximately 465 meters sub-bottom. ${ }^{2}$

6) The lowermost part of the interval at approximately 465 meters sub-bottom (?) is tentatively referred to paleomagnetic Epoch 7, on the basis of the FAD of $A$. delicatus (see above), of the FAD of Discoaster quinqueramus, and on the extinction of $D$. neohamatus (see fig. 11 of Ryan et al., 1974).

\section{Correlation With Mediterranean and North African Successions}

The stratigraphic succession investigated from Cape Bojador has been correlated with five stratigraphic successions, as indicated in Figure 5. The columnar logs are drafted at the same scale, and their lithology is schematically represented in the figure. All these sections have been carefully measured and investigated recently for their content of planktonic foraminifers and calcareous nannofossils. The Izarôrene section (see Arias et al., 1977) and that of Rio Mazzapiedi which includes the Tortonian stratotype (Cita and Blow, 1969; Martini, 1975; Ryan et al., 1974; d'Onofrio et al., 1975; Rio et al., 1976; Mazzei, 1977) are late Miocene in age, whereas the Bou Regreg section (Feinberg and Lorenz, 1970; Cita, 1974; Bossio et al., 1976; Wernli, 1977) extends from the late Miocene to the early Pliocene. The other sections considered from the Mediterranean (DSDP Site 132, see Cita, 1973a, b; Stradner, 1973; Bukry, 1973c) and Capo Rossello (see Cita, 1975a; Cita and Gartner, 1973; Cita and Decima, 1975; Gartner, 1977) are mainly Pliocene in age, and extend beyond the Miocene/Pliocene boundary. As indicated in Figure 5, the correlations are as follows, from bottom to top: ${ }^{3}$

LAD of Discoaster hamatus. This datum allows a fairly good correlation with the stratotype section of the Tortonian stage. The biostratigraphic position of the basal beds exposed in the Rio Mazzapiedi section cannot be defined precisely because of the lithology, which is unfavorable to the preservation of calcareous nannofossils.

FAD of Discoaster berggrenii. This datum, as the previous one, can be correlated from the Cape Bojador succession to the Tortonian stratotype; in this latter section, however, the first local occurrence seems to be delayed by a facies control.

FAD of Amaurolithus delicatus. This biohorizon can be identified in all the Miocene sections considered here, as well as in several additional ones from the Mediterranean area (Falconara, Mussotto, Sant'Agata, Cropalati; see Rio et al., 1976), where it occurs close to the FAD of Globorotalia conomiozea. This biostratigraphic event has been proposed by d'Onofrio et al. (1975) as a biostratigraphic criterion to locate the Tortonian/Messinian

\footnotetext{
${ }^{2}$ Extremely poor core recovery in Cores 50 and 51 and the occurrence of a 9-meter-thick uncored interval between these two cores result in lack of precision in this particular calibration.

${ }^{3}$ Only the correlations based on calcareous nannofossils are discussed here with the exception of the FAD of Globorotalia conomiozea.
} 


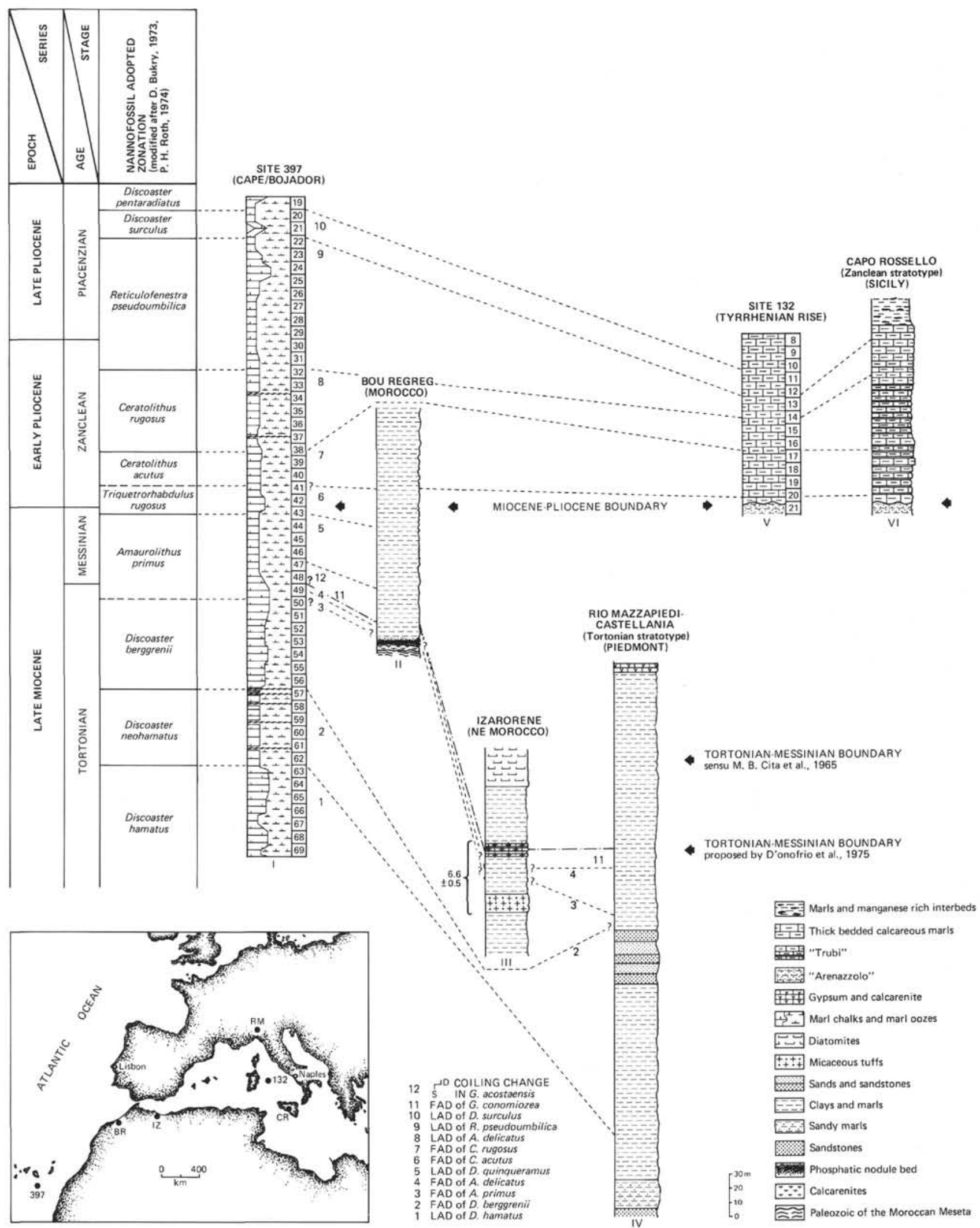

Figure 5. Correlation of the late Neogene succession of DSDP Site 397 (Cores 19-57) with the Bou Regreg and Izarôrene sections of Morocco, and with classical Mediterranean sections by means of calcareous nannofossils (datums 1-10) and of planktonic foraminifers (datums 11-12). 
boundary. In the Melilla section, the Ceratoliths are extremely rare, and $A$. delicatus has not been recorded. Therefore, the correlation is essentially founded on the FAD of $G$. conomiozea.

LAD of Discoaster quinqueramus. This biohorizon has been recorded at Site 397 and in the Bou Regreg section of Morocco. In both sections, a distinct overlap of this taxon and of Globorotalia margaritae is noticed. In the Mediterranean area, this event cannot be precisely located, since it occurs during the salinity crisis of the Messinian.

FAD of Ceratolithus acutus. This event is interesting for the calibration of the Miocene/Pliocene boundary, since it has been recognized only 6 meters above the boundary stratotype designated at Capo Rossello, Sicily (Cita, 1975a; Gartner in Cita and Gartner, 1973). Unfortunately, the taxon is extremely rare at Site 397; the reliability of this datum is supported, as previously mentioned, by the extinction of Triquetrorhabdulus rugosus.

FAD of Ceratolithus rugosus. This datum is recognized at Site 397 and in the Mediterranean (Site 132, Tyrrhenian Basin and Capo Rossello section, references as above and Stradner, 1973; Cita and Ryan, 1973).

LAD of Amaurolithus delicatus (i.e., Ceratolithus tricorniculatus extinction datum Auctorum). This event is recognizable at Site 397 and in the Mediterranean sections here discussed. As previously mentioned, this datum in Core 32 is difficult to locate with precision due to the likelihood of reworking from lower stratigraphic levels. At Site 397, the datum falls near the base of the Matuyama Magnetic Epoch whereas, in Pacific Ocean piston cores, the datum has been identified within the uppermost normal polarity interval of the Gauss Epoch (Gartner, 1973), and in the Mediterranean, it has been located just below this normal polarity interval (Stradner, 1973; Ryan and Flood, 1973). The paleomagnetic record from the Mediterranean is not of satisfactory quality because the samples were only AF demagnetized at 50 Oe. Hence, the possibility exists that the thickness of the $R$. pseudoumbilica Zone is overly exaggerated at Site 397.

LAD of Discoaster surculus. As for the previous datum, the extinction of D. surculus in land-based sections is subject to uncertainties due to the possibility of reworking. The calibration of this datum with reference to the reversal sequence is somewhat different at Sites 397 and 132; in the latter, it is correlated with the top of the Gauss Epoch, whereas in the former it correlates with the lower Matuyama Epoch. The location of this biostratigraphic datum as recorded at Site 397 is in good aggreement with Gartner's (1973) paleomagnetic calibration.

Calibration of the Cape Bojador Succession With Late Neogene Stage Boundaries and Epoch Boundaries

\section{Tortonian/Messinian Boundary}

On Figure 5, we indicate the location of the Tortonian/Messinian boundary in the Rio Mazzapiedi stra- totype section according to the definition of Cita et al. (1965, see also Cita and Blow, 1969; Ryan et al., 1974), based on the first impoverishment of marine fauna, and according to the new biostratigraphic definition of d'Onofrio et al. (1975), based on the first occurrence of Globorotalia conomiozea. For Site 397, we attempt to adopt the latter boundary, though the zonal indicator ( $G$. conomiozea) is not recorded (see Salvatorini and Cita, this volume). We are required, therefore, to use the FAD of Amaurolithus delicatus, a biostratigraphic event closely predating the FAD of $G$. conomiozea in many sections in the Mediterranean.

The Tortonian/Messinian boundary, identified as above, falls between Sections 49-1 and Section 48-6, at approximately 460 meters sub-bottom. It is correlated to the lowermost part of paleomagnetic Epoch 6, whose base on the paleomagnetic time scale of Ryan et al. (1974) is 6.5 m.y.B.P. This age estimate is in good agreement with the radiometric dates of 6.6 m.y.B.P. ( \pm 0.5 m.y.) in the Melilla section of Morocco (Arias et al., 1976) and of 6.8 m.y.B.P. on the Barquero volcano of southern Spain (van Couvering et al., 1976) in stratigraphic levels correlated with or just below the $G$. conomiozea FAD.

\section{Miocene/Pliocene Boundary}

The Miocene/Pliocene boundary (i.e., Messinian/ Zanclean boundary) has its stratotype in Sicily at the base of the "Trubi" Formation at Capo Rossello (Cita, 1975a; Cita and Gartner, 1973; Cita and Proto Decima, 1975; Rio et al., 1976). This boundary falls within the range of Amaurolithus delicatus and Globorotalia margaritae, close to the FAD of Sphaeroidinella, after the LAD of Discoaster quinqueramus, and slightly before the FAD of Ceratolithus acutus. In the Mediterranean area, the Miocene/Pliocene boundary, defined as above, coincides with the re-establishment of open marine conditions after the Messinian salinity crisis and with a marked lithologic and faunal break, which does not involve any significant time gap.

If we apply the biostratigraphic criteria mentioned above to the Cape Bojador succession, we find the following location of FADs and LADs: FAD of Globorotalia margaritae in Section 45-1, LAD of Discoaster quinqueramus in Section 43-4, FAD of Ceratolithus acutus in Section 39-5.

Due to the scattered occurrence of the last taxon at Site 397, we rely on the LAD of Triquetrorhabdulus rugosus, which is virtually coincident with the FAD of $C$. acutus in cores rich in Ceratoliths, and which is recorded up to Section 41-3. Consequently, the best estimate we can offer for a biostratigraphic correlation of the Miocene/Pliocene boundary is at the base of Core 42, at approximately 398 meters sub-bottom.

On the basis of previous works (see Hays et al., 1969; Berggren and van Couvering, 1974; Ryan et al., 1974; Gartner, 1973; Cita, 1975a; Saito et al., 1975), this boundary falls very close to the Gilbert/Epoch 5 boundary.

In the paleomagnetic stratigraphy worked out for Site 397 , we recorded a magnetic reversal from normal 
(below) to reversed (above) at 397 meters sub-bottom, which should match this epoch boundary.

\section{Zanclean/Piacenzian Boundary}

In the sequence of standard marine stages of the Neogene, two names are commonly used for the lower subdivision of the Pliocene, i.e., Zanclean and/or Tabianian. The biostratigraphic extension of the two stratotype sections is not identical, as discussed by Cita (1975a, pp. 22-24), the Zanclean being more extended both downwards and upwards than the Tabianian. The name Zanclean is adopted here because (1) its base coincides with the Miocene/Pliocene boundary stratotype, and (2) the term has been adopted at the 25th International Geological Congress (Syndey, 1976, see Geological Newsletter, v. 1976, p. 322).

Following the principle that the top of a stage is defined by the base of the following stage (Hedberg, 1976), we locate the Zanclean/Piacenzian boundary by correlation with the base of the Piacenzian stage, at Castellarquato. The biostratigraphic event closest to this boundary in the type section is the LAD of Globorotalia margaritae. The LAD of the genus Amaurolithus is recorded slightly below the base of the stage and slightly below the LAD of $G$. margaritae (Barbieri et al., 1974). The LAD of Amaurolithus is recorded at Site 397 in Section 32-2. We locate the stage boundary above that level using the LAD of G. margaritae, at the top of Core 29 , at approximately 266 meters subbottom.

\section{ACKNOWLEDGMENTS}

Financial support has been provided by Consiglio Nazionale delle Ricerche through Grants 76.0085 .05 to M.B.C. (Messinian coordinated Research Group), 76.00133.05 to D.R. (Paleopelagos coordinated Research Group), and 76.00137 .05 to R.M. (Messinian coordinated Research Group).

One of us (N. H.) wishes to thank D. Spanner for technical assistance.

The present manuscript has been critically revised by W. B. F. Ryan, F. Proto Decima, F. Barbieri, R. C. Wright, and L. H. Burckle.

\section{REFERENCES}

Arias, C., Bigazzi, G., Bonadonna, F. P., Brigatti, M. F., Morlotti E., Radicati Di Brozolo, F., Rio, D., Tirelli, G., and Torelli, L., in press. Chronostratigraphy of the Izarôrene Section in the Melilla Basin (NE Morocco), Boll. Soc. Geol. Ital.

Barbieri, F., Morlotti, E., Palmieri, G., Rio, D., and Torelli, L., 1976. Biostratigraphy of the Izarôrene Section in the Melilla Basin (NE Morocco), VII African Micropaleot. Coll. ILE-IFE, Nigeria.

Barbieri, F., Palmieri, G., and Rio, D., 1975. Calcareous nannoplankton from western Sicily Emily Pliocene (including the Piacenzian Stratotype). VI R. C. M. N.S. Congress, Bratislava, preprint.

Berrggren, W. A. and van Couvering, R., 1974. Geological Newsletter, v. 1976, p. 322.

Bossio, A., El-Bied Rakich, K., Giannelli, L., Mazzei, R., Russo, A., Salvatorini, G., 1976. Corrélation de quelques sections stratigraphiques du Mio-Pliocène de la zone At- lantique du Maroc avec les stratotypes du Bassin Mediterranéen sur la base des foraminiferres planctoniques, nannoplancton calcaire et ostracodes, Atti Soc. Tosc. Sc. Nat. Mem., Pisa, v. LXXXIII, p. 121-137.

Bramlette, M. N. and Wilcoxon, J. A., 1967. Middle Tertiary calcareous nannoplankton of the Cipero Section, Trinidad W. I., Tulane Studies Geology, v. 5, p. 93-131.

Bukry, D., 1971a. Discoaster evolutionary trends, Micropaleontology, v. 17, p. 43-52.

1971b. Cenozoic calcareous nannofossils from the Pacific Ocean, San Diego Soc. Nat. Hist. Trans., v. 16, p. 303-328.

1972. Coccolith stratigraphy, Leg 14, Deep Sea Drilling Project. In Hayes, D. E., Pimm, A. C., et al., Initial Reports of the Deep Sea Drilling Project, v. 14; Washington (U. S. Government Printing Office), p. 487493.

1973a. Coccolith stratigraphy, eastern equatorial Pacific, Leg 16 Deep Sea Drilling Project, In van Andel, T. H., Heath, G. R., et al., Initial Reports of the Deep Sea Drilling Project, v. 16: Washington (U.S. Government Printing Office), p. 653-711.

, 1973b. Phytoplankton stratigraphy, Deep Sea Drilling Project Leg 20, Western Pacific Ocean. In Heezen, B. C., MacGregor, I. D., et al., Initial Reports of the Deep Sea Drilling Project, v. 20: Washington (U. S. Government Printing Office), p. 307-317.

1973c. Coccolith stratigraphy, Leg 13 Deep Sea Drilling Project. In Ryan, W. B. F., Hsü, K. J., et al., Initial Reports of the Deep Sea Drilling Project, v. 13, Part 2: Washington (U. S. Government Printing Office), p. 817821.

1973d. Low-latitude coccolith biostratigraphic zonation. In Edgar, N. T., Saunders, J. B., et al., Initial Reports of the Deep Sea Drilling Project, v. 15: Washington (U.S. Government Printing Office), p. 685-703.

1975a. Phytoplankton stratigraphy, southwest Pacific, Deep Sea Drilling Project Leg 30. In Andrews, J. E., Packham, G., et al., Initial Reports of the Deep Sea Drilling Project, v. 30: Washington (U.S. Government Printing Office), p. 539-547.

1975b. Coccolith and silicoflagellate stratigraphy, Northwestern Pacific Ocean, Deep Sea Drilling Project Leg 32. In Larson, R. L., Moberly, R., et al., Initial Reports of the Deep Sea Drilling Project, v. 32: Washington (U.S. Government Printing Office), p. 677-701.

1976. Coccolith stratigraphy of Manihiki Plateau, Central Pacific, Deep Sea Drilling Project, Site 317. In Schlanger, S. O., Jackson, E. D., et al., Initial Reports of the Deep Sea Drilling Project, v. 33: Washington (U.S. Government Printing Office), p. 493-501.

Bukry, D. and Bramlette, M. N., 1969. Some new and stratigraphically useful calcareous nannofissils of the Cenozoic, Tulane Studies Geology, v. 7, p. 131-142.

Bukry, D. and Percival, S. F., 1971. New Tertiary calcareous nannofossils, Tulane Studies Geology, v. 8, p. 123-146.

Cati, F. and Borsetti, A. M., 1970a. I Discoasteridi del Miocene delle Marche, Giorn, Geol., v. 26, p. 617-652.

Cati, F. and Borsetti, A. M., 1970b. Nannoplancton Calcareo. Ricerche Geologiche preliminari nel Mar Tirreno. Giorn. Geol., Bologna, v. 37, p. 129-136.

Cita, M. B., 1971. Biostratigraphy, chronostratigraphy and paleoenvironment of the Pliocene of Cape Verde (North Atlantic), Revue de Micropaléontologie, v. 5. 1973a. Inventory of biostratigraphical findings and problems. In Ryan, W. B. F., Hsü, K. J., et al., Initial 
Reports of the Deep Sea Drilling Project, v. 13: Washington (U.S. Government Printing Office), p. 1045-1065.

1973b. Pliocene biostratigraphy and chronostratigraphy. In Ryan, W. B. F., Hsü, K. J., et al., Initial Reports of the Deep Sea Drilling Project, v. 13: Washington (U. S. Government Printing Office), p. 1343-1379.

1974. Il significato geodinamico della crisi di salinità del Miocene terminale nel Mediterraneo, Relazione C.N.R., Roma, p. 22-23.

1975a. The Miocene/Pliocene boundary: History and definition. In Saito, T. and Burckle, L. H. (Eds.), Late Neogene epoch boundaries: New York (Micropaleontology Press), p. 1-30.

1975b. Planktonic foraminiferal biozonation of the Mediterranean Pliocene deep sea record. A revision, Riv. Ital. Paleont., Milano, v. 81, p. 527-544.

Cita, M. B. and Blow, W. H., 1969. The biostratigraphy of the Langhian, Serravallian and Tortonian Stages in the type-sections in Italy, Riv. Ital. Paleont., Milano, v. 75, p. 549-603.

Cita, M. B. and Gartner, S., Jr. 1973. The stratotype Zanclean: Foraminiferal and nannofossil biostratigraphy, Riv. Ital. Paleont., Milano, v. 79, p. 503-588.

Cita, M. B., Stradner, H., and Ciaranfi, N., 1973. Biostratigraphical investigations on the Messinian stratotype and on the overlying "Trubi" formation, Riv. Ital. Paleont., Milano, v. 79 , p. 393-446.

Cita, M. B. and Decima, A., 1975. Rossellian: proposal of a superstage for the marine Pliocene. In VI Congr. Proc., Bratislava, v. 1, p. 217-227.

D’Onofrio, S., Giannelli, L., Iaccarino, S., Morlotti, E., Romeo, M., Salvatorini, G., Sampò, M., and Sprovieri, R., 1975. Planktonic foraminifera of the upper Miocene from some Italian sections and the problem of the lower boundary of the Messinian, Boll. Soc. Paleont. It., Modena, v. 14, p. 177-196.

Edwards, A. R. and Perch-Nielsen, K., 1975. Calcareous nannofossils from the southwest Pacific, Deep Sea Drilling Project Leg 29. In Kennett, J. P., Houtz, R. E., et al., Initial Reports of the Deep Sea Drilling Project, v. 29: Washington (U.S. Government Printing Office), p. 469-539.

Feinberg, H. and Lorenz, H. G., 1970. Nouvelles données stratigraphiques sur le Miocene supérieur et le Pliocène du Maroc nord-occidental, Notes Serv. Geol. Maroc., v. 30, p. 21-16.

Fischer, A. G. and Arthur, M. A., 1977. Secular variations in the pelagic realm. Basinal Carbonate Sediments, S.E.P.M. Special Publ.

Gartner, S., Jr., 1967. Calcareous nannofossils Neogene of Trinidad, Jamaica, and Gulf of Mexico, Univ. Kansas Publ. State Geol. Surv. Paleontol. Contr., v. 29, p. 1-7.

1969. Correlation of Neogene planktonic foraminifera and calcareous nannofossil zones, Gulf Coast Assoc. Geol. Soc. Trans., v. 19, p. 585-599.

1973. Absolute chronology of the late Neogene nannofossil succession in the Equatorial Pacific, Geol. Soc. Am. Bull., v. 84, p. 2021-2034.

1977. The calcareous nannofossils of the Monte Narbone Formation., Riv. Ital. Paleont., Milano.

Gartner, S. and Bukry, D., 1975. Morphology and phylogeny of the Coccolithophycean family Ceratolithaceae, $R \boldsymbol{e}$ search U. S. Geol. Survey, v. 3, p. 451-465.

Hay, W. W., 1972. Probabilistic stratigraphy, Eclogae Geol. Helvetiae, v. 65 p. 255-266.

Hay, W. W. and Beaudry, F. M., 1973. Calcareous nannofossils-Leg 15 Deep Sea Drilling Project. In Edgar, N. T., Saunders, J. B., et al., Initial Reports of the Deep Sea Drill- ing Project, v. 15: Washington (U.S. Government Printing Office), p. 625-683.

Hay, W. W., Mohler, H., Roth, P. H., Schmidt, R. R., and Boudreaux, J. E., 1967. Calcareous nannoplankton zonation of the Cenozoic of the Gulf Coast and Caribbean-Antillean area, and transoceanic correlation, Gulf Coast Assoc. Geol. Soc. Trans., v. 17, p. 428-480.

Hays, J. D., Saito, T., Opdyke, N. D., and Burckle, L. H., 1969. Pliocene-Pleistocene sediments of the equatorial $\mathrm{Pa}$ cific: their paleomagnetic, biostratigraphic, and climatic record, Geol. Soc. Am. Bull., v. 80, p. 1481-1514.

Hedberg, H. D., 1976. International Stratigraphic Guide: A guide to stratigraphic classification, terminology and procedure: New York (Wiley \& Sons).

Hekel, H., 1973. Late Oligocene to Recent nannoplankton from the Capricorn Basin (Great Barrier Reef Area), $\mathrm{Pa}$ leontol. Papers, Geol. Surv. Queensland, publ. no. 359, v. 33 .

Martini, E., 1969. Nannoplankton aus dem Miozän von Gabon (Westafrica), N. Jb. Geol. Paläont. Abh., v. 132, p. 285-300.

1971. Standard Tertiary and Quarternary calcareous nannoplankton zonations. In Farinacci, A. (Ed.), II Plankt. Conf. Proc. Roma: Rome (Tecnoscienza), p. 739-785.

$\longrightarrow$ 1975. Calcareous nannoplankton from the type Tortonian (Upper Miocene), R.C.M.N.S. VI Congr. Proc., Bratislava.

Martini, E. and Bramlette, M. N., 1963. Calcareous nannoplankton from the experimental Mohole drilling, J. Paleontol., v. 37, p. 845-856.

Martini, E. and Worsley, T., 1971. Tertiary calcareous nannoplankton from the western equatorial Pacific. In Winterer, E. L., Riedel, W. R., et al., Initial Reports of the Deep Sea Drilling Project, v. 7: Washington (U.S. Government Printing Office), p. 1471-1507.

Mazzei, R., 1977. Biostratigraphy of the Rio MazzapiediCastellania (Type-section of the Tortonian) based on calcareous nannoplankton, Atti Soc. Tosc. Sci. Nat. Mem., Pisa, Ser. A, v. 84.

Müller, C., 1974. Calcareous nannoplankton, Leg 25 (Western Indian Ocean). In Simpson, E. S. W., Schlich, R., et al., Initial Reports of the Deep Sea Drilling Project, v. 25: Washington (U.S. Government Printing Office), p. 579633.

Proto Decima, F., 1974. Leg 27 calcareous nannoplankton. In Veevers, J. J., Heirtzler, J. R., et al., Initial Reports of the Deep Sea Drilling Project, v. 27: Washington (U.S. Government Printing Office), p. 589-621.

Rade, J., 1975. Scyphosphaera evolutionary trends with special reference to eastern Australia, Micropaleontology, v. 21, p. 151-164.

Rio, D., Mazzei, R., and Palmieri, G., 1976. The stratigraphic position of the Mediterranean upper Miocene evaporites, based on nannofossils, Mem. Soc. Geol., v. 16.

Roth, P. H., 1973. Calcareous nannofossils-Leg 17, Deep Sea Drilling Project. In Winterer, E. L., Ewing, J. L., et al., Initial Reports of the Deep Sea Drilling Project, v. 17: Washington (U.S. Government Printing Office), p. 695795.

1974. Calcareous nannofossils from the north western Indian Ocean, Leg 24 Deep Sea Drilling Project. In Fischer, R. L., Bunce, E. T., et al., Initial Reports of the Deep Sea Drilling Project, v. 24: Washington (U.S. Government Printing Office), p. 969-993.

Roth, P. H. and Thierstein, H., 1972. Calcareous nannoplankton: Leg 14 of the Deep Sea Drilling Project. In 
Hayes, D. E., Pimm, A. C., et al, Initial Reports of the Deep Sea Drilling Project, v. 14: Washington (U.S. Government Printing Office), p. 421-485.

Roth, P. H., Franz, H. E., and Wise, S. W., Jr., 1970. Morphological Study of Selected members of the genus Sphenolithus Dflandre. In Farinacci, A. (Ed.), II Plank. Conf. Proc. Roma: Rome (Tecnoscienza), p. 1099-1119.

Ryan, W. B. F., Cita, M. B., Dreyfus Rawson, M., et al.,1974. A paleomagnetic assignment of Neogene stage boundaries and the development of isochronous datum planes between the Mediterranean, the Pacific and Indian Ocean in order to investigate the response of the world oceans to the Mediterranean "Salinity Crisis," Riv. Ital. Paleont., v. 80 , p. 631-688.

Ryan, W. B. F., and Flood, J. D., 1973. Preliminary paleomagnetic measurements on sediments from the Ionian (Site 125) and Tyrrhenian (Site 132) basins of the Mediterranean. In Ryan, W. B. F., Hsü, K. G., et al., 1973. Initial Reports of the Deep Sea Drilling Project, v. 13: Washington (U.S. Government Printing Office), p. 599-604.

Sachs, J. B. and Skinner, H. C., 1973. Late Pliocene, early Pleistocene nannofossils stratigraphy in the North Central Gulf Coast Area, Symp. Calcar. Nannofossils Gulf Coast Sect. Proc. Houston, p. 94-125.

Saito, T., Burckle, L. M., Hays, J. (Eds.), 1975. Late Miocene to Pleistocene biostratigraphy of Equatorial Pacific sediments. Late Neogene epoch boundaries (XXIV Interna- tional Geological Congress, Montreal, 1972, Symposium 109), Am. Mus. Nat. Hist., Micropal., p. 226-244.

Schmidt, R. R., 1973. A calcareous nannoplankton zonation for upper Miocene-Pliocene deposits from the southern Aegean Area, with a comparison to Mediterranean stratotype localities, Proc. Kon. Ned. Akad. Wet., Amsterdam, v. 76, p. $287-310$

Smith, L. A., 1977. Messinian Event, Geotimes, v. 3, p. 20-23.

Stainforth, R. M., Lamb, J. L., Iuterbacher, H. P., Beard, J. H., and Jeffords, R. M., 1975. Cenozoic planktonic foraminiferal zonation and characteristic index forms, The Univ. Kansas Paleontol. Contrib., Article 60, p. 1-425.

Stradner, H., 1973. Catalogue of calcareous nannoplankton from sediments of Neogene age in the Eastern Atlantic and Mediterranean Sea. In Ryan, W. B. F., Hsü, K. J., et al., Initial Reports of the Deep Sea Drilling Project, v. 13: Washington (U.S. Government Printing Office), p. 1137 1199.

van Couvering, J. A., Berggren, W. A., Drake, R. E., Aguirre, E. and Curtis, G. H., 1976. The Terminal Miocene Event, Marine Micropaleontology: Amsterdam (Elsevier), v. 1, p. 263-286.

Wernli, R., 1977. Les foraminiferes planctoniques de la Limite Mio-Pliocene Dans Les Environs de Rabat (Maroc), Eclog. Geol. Helv., v. 70, p. 143-191.

Zachariasse, W. J., 1975. Planktonic foraminiferal biostratigraphy of the late Neogene of Crete (Greece), Utrecht, Micropal. Bull., v. 11, p. 1-171. 